\title{
Electrical business mode development trend of traditional clothing brand
}

\author{
Junping Hua ${ }^{1, a}$ \\ ${ }^{1}$ Jiangxi Institute of Fashion Technology, Jiangxi, Nanchang, 330201 \\ a120711423@qq.com
}

Keywords: Electronic commerce; Traditional clothing brand; Clothing industry; trend

\begin{abstract}
The development of electronic commerce for the traditional garment industry is not only a huge impact, also a boundless potential opportunity. In this paper, the electronic commerce to the traditional garment industry market and briefly analyzed the influence of consumer behavior, and accordingly puts forward under the influence of traditional clothing brand in the electricity business model, will gradually toward the online common development, pay attention to the products and end user interaction, and enhance the user's personal experience of the three development trends.
\end{abstract}

\section{Introduction}

In the $1980 \mathrm{~s}$, with the rapid development of computer technology and Internet, the world's business pattern and economic mode has received the unprecedented impact, electricity as the main way of emerging Internet industry worldwide at breakneck speed, the traditional industry struggling between faults in this business, hope that through the transformation of the enterprise itself conform to the trend of The Times, so as not to be eliminated by the society. So, each brand on the Internet in mind, use the power of the web to open new journey.

\section{The influence of e-commerce to the traditional industry analysis}

Market shocks. According to relevant data statistics, in 2006 China's urban population average network shopping rate lower than $10 \%$, by 2010 , however, only four years time, the ratio has climbed to 23\%. Release data at the same time, the China Internet network information center, 2011, said this year in our country network shopping user number nearly close to 200 million person-time, increased by $20.8 \%$ over the previous year. In addition, the Boston company in to our country network shopping situation after the digital investigation of prediction: in the next few years, China's online shopping users will continue to maintain rapid growth in recent years.

With the increasing of network users and online visitors directly to promote Chinese traditional garment industry and electronic commerce. A gathering area for customers are also great changes have taken place: from the line of urban youth groups quickly spread to two or three cities, and even the stages of rural customers. As shown in figure 1, e-commerce on the impact of the apparel market, the largest market share occupied the most serious. Analyzed data from 2008 to 2014 showed that after the apparel network shopping compound growth rate of $125 \%$, among the top of the all products category.

Table 1 Electronic business impact analysis of the categories

\begin{tabular}{|c|c|c|}
\hline category & The impact analysis & The influence degree \\
\hline Apparel & $\begin{array}{c}\text { Consumption is huge, the network to buy more } \\
\text { convenient and cheaper, network shopping pre-sale } \\
\text { system is established }\end{array}$ & The biggest \\
\hline $\begin{array}{c}\text { Home appliance } \\
\text { digital class }\end{array}$ & $\begin{array}{c}\text { Convenient to buy cheap, small differences, consumption } \\
\text { in general, but needs to improve after-sale system }\end{array}$ & Great \\
\hline Books and food & Relatively easy to standardization, the price is cheaper & Large \\
\hline Butch make-up class & .Online sales, customers have doubts & General \\
\hline Gold jewelry class & Unable to identify the brand, quality, material and so on & Small \\
\hline
\end{tabular}


According to Nielsen survey released in 2011, about $43 \%$ of the second-tier cities respondents tend to online shopping, in order to enjoy more affordable price. , can be inferred on the basis of electronic commerce in the future must be a bigger impact on the traditional physical market, the network market share will be along with the network popularization, the rapid growth of the e-commerce is the main trends of development of garment industry in the future.

The impact on the consumer behavior. In the process of business transactions, information asymmetry constitute the seller's main source of income. However, under the network environment, information gradually tend to be transparent, price compared to the implementation of the "super sale" exit the market gradually. Network to provide consumers with the extremely rich to choose products, consumers can use the least amount of time from suppliers or retailers for detailed product information. At the same time, consumers are all kinds of interference also gradually changed from the outside. For example, in the past physical shopping consumers may be affected by the location, sales staff; And on the Internet, consumers shopping is more affected by other network consumers' product evaluation. Then, on the Internet, in addition to various products retail site, a lot of price comparison website, user recommendation rating website arises at the historic moment. These sites using the analysis tool, to contrast function analysis, the different products or the price of same product analysis, and indirectly, to guide and influence consumer buying behavior. The emergence of these analysis tools, to further alleviate the information asymmetry phenomenon between the sellers of consumers, makes further increase transparency.

Impact on producers of decision-making. Garment industry in the past, the information is in a state of unidirectional flow. And on the Internet, clothing manufacturers need to have the ability to constantly interact with users, in order to more quickly understand the demand of consumer preferences. Especially emerging big data processing in recent years, allowing producers to during the process of consumers to browse the site to understand the needs of the consumers, targeted for advertising geared to the needs of target customers, and production of apparel design decisions. Many clothing brands on the Internet to build their own network platform, constantly interact with customers. On the one hand, to understand the consumption needs of customers, and pass the latest clothing styles in the first place to the target customers, on the other hand emotional communication with customers, increase customer's brand.

\section{The future of traditional clothing brand electric business development trend}

Combination of online. As the electronic commerce is the most developed country in the United States, can you give me a electronic commerce development of garment industry to provide reference to many places. In the United States, the first five top e-commerce group, about $41 \%$ for pure electric group, $30 \%$ for traditional retailers develop e-commerce. The United States, according to a ranking in the top 10 in the electricity business, only one is pure network electronic commerce, the other nine are online business together. We can draw some conclusions from these data, for the traditional garment industry, the sound development of offline business makes it more business resources to develop e-commerce, and online business and can further consolidate its dominant position in the offline. If these garment industry to actively use the Internet technology, for the development of online and offline is a contributing factor.

Pay more attention to the interaction with end users. Marketing is a constantly found that users need, and continuously meet the demand of the user process. Especially the B2C e-commerce mode of business development, greatly shortens the distance between the brand and terminal customers, network platform has made it possible to face-to-face communication. For clothing products manufacturers, the need to master in the process of face to face with the customer's customer's complete consumption data, accurate grasp the consumption data of customer and consumer habits, sufficient insight into the potential demand of consumption and mining or did not meet the demand, then make production according to the actual needs of the market and consumers, in view of the target population for targeted marketing and sales, at the same time, receives 
consumer feedback, enhance consumer satisfaction in the brand, enhance brand value, enhance customer satisfaction. In the traditional garment industry, the lack of feedback and interaction this link, it may cause product out of stock or unsalable. Under the background of electronic commerce, production decision is no longer a strict death procedures, but ongoing feedback adjustment of dynamic operation process.

Enhance service design, create a personal experience. Service design refers to the customers in the process of product selection, purchase and use customer experience. Under the background of new economy, "product + services" 'product experience will be the key to success. In the traditional business mode, the enterprise the management goal is to maximize the profit maximization and social value. The past e-commerce is just to trade on the net, to save the cost, time does not really touched the consumer society anxiety. But Duan Yongchao think China has begun to gradually moving towards' anaerobic consumption era, that is, to possess, show as the main purpose of consumption age has faded away, instead of "whole process personal experience" give priority to the new era of consumption. And under the background of current can outlook, future consumption should be based on the joy and satisfaction, the sellers need to be cold 'trading' into some like it hot "exchanges". That is to say, the brand to provide for the customer is not the simple sense of the clothing, but also to provide spiritual enjoyment. And these additional brand experience, is a separate offline shops can provide completely, you need to clothing brand, relying on e-commerce platforms, enhance brand image, to provide users with better brand story. Let the customer feel her to buy is not only a costume, more represents a better life, and the pursuit of beauty. These contact the needs of the customers will not be expressed clearly in the process of its purchases, the companies need to do is from scratch insight into the user's psychology, from the details meet the demand of users is difficult to use language to express stealth, increase its individual before consumption, consumption and consumption in the whole process of experience.

\section{Conclusion}

From what has been discussed above, for traditional clothing brand to enter the electronic commerce, prospect is good, opportunities including eliminate geographical restrictions to increase customer base coverage, timely tracking dynamic demand and provide targeted products experience, reduces the transaction process, save time cost, etc. The increase of online sales and publicity channels, it is for traditional clothing brand development is of great significance. But at the same time we should see, in such a market, the strength and innovation will become a brand is an important factor of standing. In such a fierce competitive environment, no reform will be eliminated by the market. Clothing brand enterprises also need from too focused on the design of the product itself, transferred to the product, the user needs, the focus of personal experience, and other balance position, to stand out in the tide of the market.

\section{Reference}

[1] zhou jing. Shi Pengcheng. Garment industry electricity model comparison and development trend analysis [J] logistics technology, 2015 (3) : 11-14.

[2] Chen Mingyi. Sales data from the network to see clothing industry electric business model development [J] of shandong textile economy, 2015 (01) : 23-27.

[3] qiao-ling wang; Wang Jin variable; Wuhan. Our country network clothing brand management and administration of sustainable development analysis [J], 2011 (9) : 34 to 37.

[4] Liu Beifen; Li; RuiFei. Internet thinking under the network original clothing brand survival [J] kaifeng education college journal, 2015 (9) : 68-79. 